\title{
Factors Affecting English Medium of Instruction within Injibara College of Teachers' Education
}

\author{
Berhanu Asaye Agajie \\ Injibara College of Teachers' Education, Injibara, Ethiopia
}

\begin{abstract}
The objective of this study was to investigate the existing factors that affect English medium of instruction in Injibara College. In this study, descriptive survey method was employed. Through stratified sampling 145 graduate students (72 male, and 73 female) from natural science, mathematics, language and social science, health and physical education departments were involved in the study. Questionnaire and focus group discussion were employing to collect data. The result of the study showed that students have positive attitude towards English as the medium of instruction. However, foreign language anxiety, English proficiency, shortage of learning resources, and deprived modular preparations were challenged English as the medium of instruction at large. Hence, English as the medium of instruction obstruct students and teachers in teaching learning process. Henceforth, further research would be conducting in English as the medium of instruction in general, within quality education in particular.
\end{abstract}

Keywords: English medium of instruction, Student, college, Challenge

DOI: $10.7176 / \mathrm{JEP} / 11-10-02$

Publication date: April $30^{\text {th }} 2020$

\section{Background of the study}

Ethiopia is a multilingual, multiethnic, and ethnically a pluralist country; there exists a minimum of 85 ethnic groups, most of them with their own distinct vernaculars. With the introduction of modern education into Ethiopia, the medium of instruction used to be English as a foreign language. In spite of the fact that linguistic and ethnic diversity of the country, English has sustained to extend being paying more domination and significance not only in education but also in business and administration. Associated outcome is that the number of tertiary level students studying their subject courses through the medium of English as a foreign language continues to increase (Coleman 2006).

The roles of English defined in Ethiopian Education and Training Policy (1994) are restricted to the educational contexts: the teaching of English as a subject in schools, the use of English as a medium of instruction, and the purposes of learning English as a foreign language. Thus, the dominant role of English in Ethiopia is educational or instructional. English is educated as a subject from grade one and is a medium of instruction from grade nine through colleges and universities nationwide. The current language education policy, which has been in place since 1994, accords high practical status to the mother tongue as the medium of instruction, particularly at the primary level transition to English at grades 5, 7, or eight depending upon the region. Apart from these nationally consistent practices, different regions have adopted different regional policies and attitudes towards English in their education system; some of the regions like the study area have made English to be the medium of instruction from grade 7 and some from grade 9.

English in Ethiopia is a medium of instruction from secondary school through higher education, but the learners' proficiency remains poor and the effectiveness of English language teaching remains always questionable, despite the efforts being undertaken by the Ethiopian government and concerned institutions (Stoddart 1986).

\section{Statement of the problem}

Thus, students who join Injibara College of teachers' education are unable to express themselves in English well. Moreover, graduates who join the world of work fail to teach in English medium of instruction. Thus, in Injibara college context, researches on implementation and challenges of English medium of instruction have not been studding. Then the general framework of this study on English medium of instruction draws attention to this anomaly and intends to fill the gap in the field of education.

\section{Objectives of the Study}

The main objective of this study is to investigate the existing challenges of English as the medium of instruction within Injibara College of teacher education.

\section{Significance of the Study}

This article is supposed to be important in numerous aspects. It is necessary to disclose how English medium curriculum is supposing and implemented by its stakeholders. As a result, this study provides feedback on the 
implementation of English medium of instruction for college students and instructors. In addition, the research can also assist teachers how their classroom practices are interpreting and recognizing by their students.

The curriculum designers will able to perceive how their decisions are practicing in the classroom. Thus, the study is anticipating supplying insights for linear program development through providing authentic and expressive data about the implementation of English medium of instruction. In addition, the results of this research possibly will offer a significant foundation for the further studies evaluating the other mechanism of English medium of instruction.

\section{Literature Review}

This subdivision explains theories and terms, which are relating to the research problem such as quality of education, English medium of instruction, the predicament between the medium of instruction and English, and factors that affect the performance of English medium.

\subsection{Quality of education and English Medium of Instruction}

The quality of education can be ting to the goals of education. Language of instruction is a means of transportation through which education is delivering. Thus, the function of the language of instruction plays an important role in order to determine the quality of education. In actual circumstances, the language of instruction is an essential medium for transmitting education from teachers to learners and among learners (Chang 2010). This can happen, when the language of teachers and students comprehend, be capable to efficiently functioning as the language of instruction.

This is due to the role that the language of instruction plays in determining the quality of education. Language of instruction is a vehicle through which education is delivering (Cost 2012). As a matter of efficiency and efficacy, only the language, which teachers and students understand, can effectively function as the language of instruction. Only when teachers and students understand the language of instruction are they able to discuss debate, ask and answer questions, ask for clarification and therefore construct and generate knowledge (Doiz, and Sierra, 2012). These are activities which are a pre-requisite to learning and whose level determines the quality of education. Thus, the language of instruction is an important factor in determining the quality of education.

\subsection{The predicament between Medium of instruction and English}

Teaching and learning activities entirely encircling actions similar to lecturing, instructing, drilling, eliciting responses, asking questions, testing, provide information, encouraging, and conducting seminars (Kırkgöz 2005.). The idea of teaching is to communicate information and its achievement depends on the fact that students can capable to follow the actual lesson and able to respond what is being taught by their teacher.

\subsection{Factors that affect the Implementation of English medium of instruction}

The study about English as a medium of instruction typically apprehensive the outlooks and observations of adopters (Colleges), implements (teachers), suppliers (material writers), change agents, but hardly ever deal with the element of student's perceptions despite perceptions of all concerned people have been important in streams of research. Therefore, student's perception is considering as an essential component of English medium education because their perceptions can influence learning behaviors and achievement and affect increasing interest of English medium learning. Determining students, views about the English medium of instruction will assist both teachers and students in the teaching learning process (Hamers \& Blanc 2000).

Student motivation is one of the key factors affecting student performance and learning. Among the most important factors that influence the motivation of students are students' interest in the content and students' perceived relevance and benefits of the language. When students perceive some benefits to their education, they will probably be more motivated to carry out well, to work hard on choosing tasks that enhance their learning and attain their goals (Csizer \& Dornyei 2005).

The attitude in this context is the way in which students think (cognitive component), feel (affective component) and intend to behave (behavioral component) towards the English medium of instruction. The environments affecting the use of language within the college are creating as much by the prevailing climate in the home and the community and society as a whole. The factor of teachers 'attitude and assessment, teacherstudents relations in class, parents 'anticipation, colleagues 'attitude, students 'own attainment are the potential sources of students 'English medium of instruction (Gardner 1972).

Anxiety is subjective, intentionally apparent outlooks of apprehension and tension, associated with commencement or stimulation of the autonomic nervous system. Anxiety can be either facilitating or debilitating. Facilitating anxiety stimulates learners to accept an approach, attitude and is eager to tackle the new learning job. Debilitating apprehension inspires learners (Ames 1992). 
Foreign language anxiety is a sensation of pressure connected with the foreign language context. Students with high levels of foreign language worry might affect attainment and may show signs of escaping behaviors such as missing class and postponing homework. Anxiety, observed as unenthusiastic inspiration can undermine students' self-confidence and discourage them in using English as a means of communication and academic purposes (Ellis 1994). The lack of proficiency in the language of instruction results in poor performance in different subjects taught in English. In other words, when students have a hard grasp of their specialized subjects, that sympathetic gives them a firm ground on which to build the foundation for English medium of instruction. However, this firm understanding, which is central to the quality of education, can be achieving when teachers and students understand the language of instruction.

There is no English speaking community in the areas where teachers and students are living. Thus, English is enclosing only in the classroom settings. Therefore, teachers and students' low proficiency lead to incompetent and unproductive instruction and learning processes. Teachers who cannot speak English confidently and correctly might be incompetent to perform their chief duties in the classroom settings (Staddart 1986). Therefore, teachers breaking in proceedings, hesitance, circumlocution, verbosity, grammatical, lexical, and articulation wrongness might distinguish much of their explanation, and this certainly will dawdling their students' grasp of the content of instruction.

If students and teachers foreign language instruction is not sufficiently developed, they will have complexity in expressing themselves in it, and this situation can create a sentiment of disappointment or subjection, which in turn might influence their self-worth or self-assurance. This circumstance hinders student's academic developments. In addition to inferior self-reliance, a deprived English proficiency of teachers may lead to students' unenthusiastic awareness of them.

Learning resources include things that facilitate learning and teaching of different subjects in English medium of instruction. The teacher's responsibility is to ensure learning resources are appropriate, accessible, identifiable and relevant to students teaching needs (Coleman 2005).

\section{Methodology}

Descriptive survey method was using to assess factors associated with English as the medium of instruction. Through stratified sampling 145 graduate students (72 male, and 73 female) from natural science, mathematics, language and social science, health and physical education departments were involved in the study. Major tools used for data collection were questionnaire and focused group discussion. In terms of questionnaire, respondents asked to rank their actual involvements on a four point Likert scale (Clason and Dormody 1994).

The necessary data were analyzing using numerically and the results of which were presenting using tables. Thus, information obtained through questionnaire and group discussions were combined with the quantitative data.

\section{Result}

This part of the study deals with presenting, analyzing and interpreting the data collected through questionnaires, and focused group discussion.

Table 1: Characteristics of respondents

\begin{tabular}{|c|c|}
\hline Sex of respondents & No. of students \\
\hline Male & $72(49.6 \%)$ \\
\hline Female & $73(50.4 \%)$ \\
\hline Qualification & $100 \%$ third year \\
\hline Total & 145 \\
\hline
\end{tabular}

As shown in table 1, 72 (49.6\%) male and 73 (50.4\%) female students were involved in the study. $100 \%$ students were graduate classes. 
Table 2: Students' self-attitude towards the English medium of instruction

\begin{tabular}{|c|c|c|c|c|c|}
\hline No. & Statements & $\begin{array}{l}\text { Strongly } \\
\text { Disagree }\end{array}$ & Disagree & Agree & $\begin{array}{l}\text { Strongly } \\
\text { agree }\end{array}$ \\
\hline 1 & $\begin{array}{l}\text { English is a superior medium of } \\
\text { instruction to Amharic }\end{array}$ & $\begin{array}{c}39 \\
(26.89 \%)\end{array}$ & $\begin{array}{c}60 \\
(41.38 \%)\end{array}$ & $\begin{array}{c}27 \\
(18.62 \%)\end{array}$ & $\begin{array}{c}19 \\
(13 \%)\end{array}$ \\
\hline 2 & $\begin{array}{l}\text { I prefer Amharic to English while } \\
\text { reflecting, questioning \& answering. }\end{array}$ & $\begin{array}{c}16 \\
(11 \%)\end{array}$ & $\begin{array}{c}28 \\
(19.3 \%)\end{array}$ & $56(38.6 \%)$ & $\begin{array}{c}45 \\
(31 \%)\end{array}$ \\
\hline 3 & $\begin{array}{l}\text { English medium of instruction makes my } \\
\text { learning of the subject matter easy. }\end{array}$ & $\begin{array}{c}9 \\
(6.2 \%)\end{array}$ & $\begin{array}{c}26 \\
(17.93 \%)\end{array}$ & $\begin{array}{c}68 \\
(46.89 \%)\end{array}$ & $\begin{array}{c}42 \\
(28.96 \%)\end{array}$ \\
\hline 4 & $\begin{array}{l}\text { I properly use English as medium of } \\
\text { instruction for reflecting, questioning \& } \\
\text { answering }\end{array}$ & $\begin{array}{r}12 \\
(8.27 \%)\end{array}$ & $\begin{array}{c}67 \\
(46.2 \%)\end{array}$ & $\begin{array}{c}52 \\
(35.86 \%)\end{array}$ & $\begin{array}{c}14 \\
(9.65 \%)\end{array}$ \\
\hline 5 & $\begin{array}{l}\text { I understand the contents of English } \\
\text { medium of instruction lessons well. }\end{array}$ & $\begin{array}{c}9 \\
(6.2 \%)\end{array}$ & $\begin{array}{c}29 \\
(20 \%)\end{array}$ & $\begin{array}{c}80 \\
(55.17 \%)\end{array}$ & $\begin{array}{c}27 \\
(18.62 \%)\end{array}$ \\
\hline 6 & $\begin{array}{l}\text { Because of difficulty of instructional } \\
\text { language, the lessons of the lecture } \\
\text { remained less important. }\end{array}$ & $\begin{array}{c}32 \\
(22.06 \%)\end{array}$ & $\begin{array}{c}33 \\
(22.75 \%)\end{array}$ & $\begin{array}{c}54 \\
(37.24 \%)\end{array}$ & $\begin{array}{c}26 \\
(17.93 \%)\end{array}$ \\
\hline 7 & $\begin{array}{l}\text { I understand the lesson better in my native } \\
\text { language }\end{array}$ & $26(17.93 \%)$ & $\begin{array}{c}38 \\
(26.2 \%)\end{array}$ & $\begin{array}{c}40 \\
(27.28 \%)\end{array}$ & $\begin{array}{c}41 \\
(28.27 \%)\end{array}$ \\
\hline 8 & $\begin{array}{l}\text { There is no English speaking community, } \\
\text { both at home \& college }\end{array}$ & $\begin{array}{c}2 \\
(1.37 \%)\end{array}$ & $\begin{array}{c}4 \\
(2.75 \%)\end{array}$ & $\begin{array}{c}19 \\
(13.10 \%)\end{array}$ & $\begin{array}{c}120 \\
(82.75 \%)\end{array}$ \\
\hline 9 & $\begin{array}{l}\text { It is amusing to listen to my friends } \\
\text { speaking English in class. }\end{array}$ & $\begin{array}{c}12 \\
(8.27 \%)\end{array}$ & $\begin{array}{c}16 \\
(11 \%)\end{array}$ & $\begin{array}{c}52 \\
(35.86 \%)\end{array}$ & $\begin{array}{c}65 \\
(44.82 \%)\end{array}$ \\
\hline 10 & $\begin{array}{l}\text { Teachers sometimes ignore me because of } \\
\text { my poor English language proficiency }\end{array}$ & $\begin{array}{c}56 \\
(38.6 \%)\end{array}$ & $\begin{array}{c}57 \\
(39.3 \%)\end{array}$ & $\begin{array}{c}19 \\
(13 \%)\end{array}$ & $\begin{array}{c}13 \\
(8.96 \%)\end{array}$ \\
\hline 11 & $\begin{array}{l}\text { My English language proficiency } \\
\text { negatively affects my result. }\end{array}$ & $(10.34 \%)$ & $\begin{array}{c}44 \\
(30.34 \%) \\
\end{array}$ & $48 \quad(33 \%)$ & $\begin{array}{c}38 \\
(26.2 \%) \\
\end{array}$ \\
\hline 12 & $\begin{array}{l}\text { I feel anxious when teachers ask me } \\
\text { questions in English }\end{array}$ & $\begin{array}{c}20 \\
(13.79 \%)\end{array}$ & $\begin{array}{c}41 \\
(28.27 \%) \\
\end{array}$ & $\begin{array}{c}60 \\
(41.37 \%) \\
\end{array}$ & $\begin{array}{c}24 \\
(16.55 \%) \\
\end{array}$ \\
\hline 13 & My reading habits are increasing. & $\begin{array}{c}5 \\
(3.44 \%)\end{array}$ & $\begin{array}{c}14 \\
(9.65 \%)\end{array}$ & $64(44.1 \%)$ & $62(42.75 \%)$ \\
\hline
\end{tabular}

Concerning statement 1, 39 (26.89\% subjects were strongly disagreed and $60(41.38 \%)$ disagreed that English was not the superior medium of instruction to Amharic. On the other hand, 27 (18.62\%) agreed and 19 $(13 \%)$ students strongly agreed that English was superior medium of instruction to Amharic. Therefore, the maximum disagreements $(68.27 \%)$ showed that English was not superior medium of instruction to Amharic.

Regarding statement 2, 16 (11\%) students were strongly disagreed and 28(19.3\%) disagreed with the idea. Conversely, 56 (38.6\%) respondents agreed and 45\% strongly agreed that they prefer Amharic to English while reflecting, questioning \& answering in the classroom setting. About $69.6 \%$ of students' agreement indicated that they desire Amharic than English for reflecting, questioning \& answering in the class activities. Therefore, code switching has often perceived as being of lower status, a strategy used by weak language performers to compensate for English language deficiency.

On the subject of statement 3, $9(6.2 \%)$ students were strongly disagreed and $26(17.93 \%)$ disagreed with the issue. In contrast, 68 (46.89\%) students were disagreed and 42 (28.96\%) strongly agreed that English medium of instruction makes their learning of subject matter complicated. This event $(75.85 \%)$ noted that English medium of instruction makes students' learning of the subject matter difficult.

In terms of statement $4,12(8.27 \%)$ students were strongly disagreed and $67(46.2 \%)$ disagreed with the idea. In contrast, 52 (35.89\%) students agreed and 14 (9.65\%) subjects' strongly agreed that English medium of instruction was complicated. As a result, the maximum number of disagreement $(54.47 \%)$ commented that students' face terrible towards reflecting, questioning \& answering in English medium of instruction.

Regarding statement 5, $9(6.2 \%)$ students were strongly disagreed and $29(20 \%)$ disagreed with the happening. About $80(55.17 \%)$ students were agreed and $27(18.62 \%)$ students strongly agreed that they might understand the contents of English medium of instruction lessons as well. Accordingly, the majority agreements $(73.79 \%)$ examined that students were capable to understand the contents of English medium of instruction lessons. Hence, student's stage of lesson understanding in English medium of instruction was good.

On the topic of instructional language difficulty, $32(22.06 \%)$ students were strongly disagreed and 33 $(22.75 \%)$ disagreed that they did not have instructional language difficulty and thus, the lessons of the lecture remained important. However, $54(37.24 \%)$ respondents were agreed and $26(17.93 \%)$ students strongly agreed that because of English language complexity, the lessons of the lecture remained less important to them. Thus, 
the maximum agreements (55.17\%) identified that student's lack of English language proficiency was negatively influencing their lesson understanding.

Concerning to statement 7, $26(17.93 \%)$ learners were strongly disagreed and $38(26.2 \%)$ disagreed that students could not understand the lesson better in their native language. Although, $40(27.28 \%)$ students were agreed, and $41(28.27 \%)$ strongly agreed that they understand the lessons better in their native language. Greater part of agreements $(55.55 \%)$ indicated that students could comprehend lessons better in their mother tongue language.

In terms of statement 8, $2(1.37 \%)$ students were strongly disagreed and four $(2.75 \%)$ respondents disagreed with existence of English speaking community both at home \& college. However, 19 (13.10\%) students were agreed and $120(82.75 \%)$ strongly agreed that there were no English speaking communities both at home \& college. The majority agreements $(95.85 \%)$ were founded that English was enclosing only in the classroom settings. Therefore, teachers and students low English proficiency lead to incompetent and unproductive instruction and learning processes.

Concerning to statement 9, $12(8.27 \%)$ students were strongly disagreed, and $16(11 \%)$ disagreed with the statement. Whereas, $52(35.86 \%)$ subjects were agreed and $65(44.82 \%)$ of them strongly agreed that it was amusing to listen their friends speaking English in the classroom setting. The idea of teaching was to communicate information and its achievement depends on the fact that students can capable to follow the actual lesson and able to respond what was being taught by their teacher. Therefore, greater number of respondents $(80.68 \%)$ endorsed that foreign language anxiety has been challenging English medium of instruction at large.

Regarding statement 10, $56(38.6 \%)$ students were strongly disagreed, and $57(39.3 \%)$ disagreed with the incident. On the other hand, $19(13 \%)$ subjects were agreed and $13(8.96 \%)$ students strongly agreed that teachers sometimes ignore them because of their poor English language proficiency. Accordingly, greater number of disagreements $(77.9 \%)$ conceded that, teachers seem to put into effect to improve students English language proficiency.

Concerning statement $11,38(26.2 \%)$ students were strongly disagreed and $44(30.34 \%)$ disagreed that their English language proficiency was not negatively affecting their results. About $48(33 \%)$ respondents were agreed and $15(10.34 \%)$ subjects strongly agreed that English language proficiency was negatively affecting their result. As previewed in the data (59.2\%) students confirmed that they were facing difficulty to understand the language of instruction.

On the topic of anxious, $20(13.79 \%)$ students were strongly disagreed and $41(28.27 \%)$ disagreed that they did not felt anxious when teachers ask them questions in English. Instead, 60 (41.37\%) of them were agreed and $24(16.55 \%)$ respondents strongly agreed that they felt anxious in the classroom setting when teachers ask them questions in English. Therefore, the majority agreements $(57.92 \%)$ portrayed that students face problems while discussing, debating, answering and asking for clarification in English medium.

Regarding statement 13, 5 (3.44\%) students strongly disagree and $14(9.65 \%)$ disagree with the thought. In addition, $64(44.1 \%)$ students agree and $62(42.75 \%)$ learners strongly agree that they were able develop their reading habits. However, teacher in their interview opposed that students' did not have reading habits.

Table 3: Students' perception towards their instructors

\begin{tabular}{|c|c|c|c|c|c|}
\hline No. & Items & $\begin{array}{l}\text { Strongly } \\
\text { Disagree }\end{array}$ & Disagree & Agree & $\begin{array}{l}\text { Strongly } \\
\text { agree }\end{array}$ \\
\hline 1 & $\begin{array}{l}\text { Instructors use entirely English as medium of } \\
\text { instruction throughout the lecture }\end{array}$ & $\begin{array}{c}19 \\
(13.1 \%)\end{array}$ & $\begin{array}{c}72 \\
(49.65 \%)\end{array}$ & $\begin{array}{c}44 \\
(30.34 \%)\end{array}$ & $\begin{array}{c}10 \\
(6.89 \%)\end{array}$ \\
\hline 2 & $\begin{array}{l}\text { Our Instructors use mother tongue while } \\
\text { teaching different subjects in English. }\end{array}$ & $\begin{array}{c}36 \\
(24.82 \%) \\
\end{array}$ & $\begin{array}{c}35 \\
(24.13 \%) \\
\end{array}$ & $60(41.37 \%)$ & $\begin{array}{c}14 \\
(9.65 \%) \\
\end{array}$ \\
\hline 3 & $\begin{array}{l}\text { Instructors use interactive \& active learning } \\
\text { techniques in the teaching English medium }\end{array}$ & $\begin{array}{c}8 \\
(5.5 \%) \\
\end{array}$ & $\begin{array}{c}29 \\
(20 \%) \\
\end{array}$ & $\begin{array}{c}65 \\
(44.82 \\
\end{array}$ & $\begin{array}{c}43 \\
(29.65 \%)\end{array}$ \\
\hline 4 & $\begin{array}{l}\text { English medium of instruction makes } \\
\text { instructors difficult to teach subject matters. }\end{array}$ & $\begin{array}{c}8 \\
(5.5 \%) \\
\end{array}$ & $\begin{array}{c}4 \\
(2.75 \%) \\
\end{array}$ & $88(60.68 \%)$ & $\begin{array}{c}45 \\
(31 \%) \\
\end{array}$ \\
\hline No. & Items & Strongly & Disagree & Agree & $\begin{array}{l}\text { Strongly } \\
\text { agree }\end{array}$ \\
\hline 5 & Instructors are confident to speak English & $14(9.65 \%)$ & $38(26.2 \%)$ & $58 \quad(40 \%)$ & $\begin{array}{c}35 \\
(24.13 \%)\end{array}$ \\
\hline 6 & $\begin{array}{l}\text { Instructors are capable of using English as } \\
\text { the medium of instruction. }\end{array}$ & $\begin{array}{c}11 \\
(7.58 \%)\end{array}$ & $66(45.5 \%)$ & $38 \quad(26.2 \%)$ & $\begin{array}{c}30 \\
(20.68 \%)\end{array}$ \\
\hline 7 & $\begin{array}{l}\text { Instructors initiated me to use English } \\
\text { medium }\end{array}$ & $\begin{array}{c}8 \\
(5.5 \%)\end{array}$ & $\begin{array}{c}17 \\
(11.72 \%)\end{array}$ & $61(42.06 \%)$ & $\begin{array}{c}59 \\
(40.68 \%)\end{array}$ \\
\hline
\end{tabular}

On the subject of statement $1,19(13.1 \%)$ students' were strongly disagreed and $72(49.65 \%)$ disagreed with the subject. About $44(30.34 \%)$ students were agreed and $10(6.89 \%)$ students strongly agreed that 
instructors use entirely English as medium of instruction throughout the lecture. This $(62.75 \%)$ contended that instructors might use their mother tongue while presenting lessons in the classroom.

With reference to statement 2, $36(24.82 \%)$ subjects were strongly disagreed and $35(24.13 \%)$ disagreed in opposition to the concept. However, $60(41.37 \%)$ respondents were agreed and $14(9.65 \%)$ respondents strongly agreed that their teachers use mother tongue while teaching different subjects in English. Therefore, learners of the foreign language need opportunity to practice the target language otherwise, mastery of English might be difficult.

The state of being with statement 3, $8(5.5 \%)$ students were strongly disagreed and $29(20 \%)$ disagreed in light of conveying thought. Whereas $65(44.82 \%)$ subjects were agreed and $43(29.65 \%)$ of them strongly agreed that teachers were able to use interactive \& active learning techniques while teaching in English medium. Greater part of respondents $(74.47 \%)$ has a tendency to agree that teachers appoint students in classroom activities. Instructors interview also revealed that the classroom activities done in the target college were copying notes from the chalkboard into the exercise books and answering questions in the classroom, discussing in a group, and reflecting issues for class students.

In line with statement $4,8(5.5 \%)$ students were strongly disagreed and four $(2.75 \%)$ subjects disagreed in opposition to the account of face. However, 88 (60.68\%) learners were agreed and $45(31 \%)$ students strongly agreed that English medium of instruction makes their instructors difficult to teach different subject matters. As a result, the majority agreements $(91.68 \%)$ assured that instructors were facing difficulties while teaching different subjects in English medium.

Regarding statement 5, $14(9.65 \%)$ subjects were strongly disagreed and $38(26.2 \%)$ disagreed that instructors were not confident to speak English. Moreover, 58 (40\%) students were agreed, and $35(24.13 \%)$ subjects strongly agreed that their teachers were confident to speak in English. Hence, several instructors were confident to speak in English in the class.

About the subject of statement 6, $11(7.58 \%)$ students were strongly disagreed, $66(45.5 \%)$ learners also disagreed with the occurrence. About $38(26.2 \%)$ respondents were agreed and $30(20.68 \%)$ students strongly agreed that teachers were capable of using English as the medium of instruction. According to the numerous views (53.08\%), teachers who cannot speak English confidently and appropriately might provide incompetent to carry out their main responsibility in the classroom settings.

Concerning item $7,8(5.5 \%)$ students were strongly disagreed, and $17(11.72 \%)$ disagreed with the statement. Furthermore, $61(42.06 \%)$ students were agreed and 59 (40.68\%) strongly agreed that teachers initiated students to use English medium. Therefore, about $82.74 \%$ of students' agreements confirmed that teachers were initiating students to use English medium.

Table 4: Students evaluation towards Learning Resources

\begin{tabular}{|c|c|c|c|c|c|}
\hline No & Items & $\begin{array}{l}\text { Strongly } \\
\text { Disagree }\end{array}$ & Disagree & Agree & $\begin{array}{l}\text { Strongly } \\
\text { agree }\end{array}$ \\
\hline 1 & $\begin{array}{l}\text { More modules are applicable to student } \\
\text { requirements and thematic interests. }\end{array}$ & $\begin{array}{c}18 \\
(12.4 \%)\end{array}$ & $\begin{array}{c}42 \\
(28.96 \%)\end{array}$ & $\begin{array}{c}53 \\
(36.55 \%)\end{array}$ & $\begin{array}{c}33 \\
(22.75 \%)\end{array}$ \\
\hline 2 & $\begin{array}{l}\text { Modular speaking, reading and writing } \\
\text { activities enable students better geared up to } \\
\text { use English in their daily lesson. }\end{array}$ & $\begin{array}{c}6 \\
(4.13 \%)\end{array}$ & $\begin{array}{c}34 \\
(23.44 \%)\end{array}$ & $\begin{array}{c}66 \\
(45.5 \%)\end{array}$ & $\begin{array}{c}39 \\
(26.89 \%)\end{array}$ \\
\hline 3 & $\begin{array}{l}\text { I do not get sufficient exposure to the } \\
\text { language the modules are prepared. }\end{array}$ & $\begin{array}{c}6 \\
(4.13 \%) \\
\end{array}$ & $\begin{array}{c}26 \\
(17.93 \%)\end{array}$ & $\begin{array}{c}65 \\
(44.82 \%)\end{array}$ & $\begin{array}{c}48 \\
(33.1 \%)\end{array}$ \\
\hline 4 & $\begin{array}{l}\text { There are high quality English medium } \\
\text { modules. }\end{array}$ & $17(11.72 \%)$ & $\begin{array}{c}51 \\
(35.17 \%)\end{array}$ & $\begin{array}{c}43 \\
(29.65 \%)\end{array}$ & $\begin{array}{c}34 \\
(23.44 \%)\end{array}$ \\
\hline 5 & Modules are free of any grammatical errors. & $32(22.06 \%)$ & $67(46.2 \%)$ & $29(20 \%)$ & $\begin{array}{c}17 \\
(11.72 \%)\end{array}$ \\
\hline 6 & $\begin{array}{l}\text { I can easily understand the contents of the } \\
\text { module. }\end{array}$ & $17(11.72 \%)$ & $\begin{array}{c}50 \\
(34.48 \%)\end{array}$ & $\begin{array}{c}62 \\
(42.75 \%)\end{array}$ & $16(11 \%)$ \\
\hline 7 & Modules are distributed one to one. & $\begin{array}{c}22 \\
(15.17 \%) \\
\end{array}$ & $\begin{array}{c}55 \\
(37.93 \%) \\
\end{array}$ & $\begin{array}{c}43 \\
(29.65 \%) \\
\end{array}$ & $\begin{array}{c}25 \\
(17.24 \%) \\
\end{array}$ \\
\hline 8 & Teachers are confident to use their modules. & $\begin{array}{c}25 \\
(17.24 \%)\end{array}$ & $\begin{array}{c}62 \\
(42.75 \%) \\
\end{array}$ & $\begin{array}{c}36 \\
(24.82 \%) \\
\end{array}$ & $\begin{array}{c}22 \\
(15.17 \%) \\
\end{array}$ \\
\hline 9 & $\begin{array}{l}\text { Modules are communicative, and enable me } \\
\text { self-learning. }\end{array}$ & $\begin{array}{c}28 \\
(19.3 \%) \\
\end{array}$ & $\begin{array}{c}46 \\
(31.72 \%) \\
\end{array}$ & $\begin{array}{c}43 \\
(29.65 \%) \\
\end{array}$ & $\begin{array}{c}28 \\
(19.3 \%) \\
\end{array}$ \\
\hline 10 & $\begin{array}{l}\text { There are enough reference materials in the } \\
\text { library. }\end{array}$ & $\begin{array}{c}22 \\
(15.17 \%)\end{array}$ & $\begin{array}{c}62 \\
(42.75 \%)\end{array}$ & $\begin{array}{c}36 \\
(24.82 \%)\end{array}$ & $\begin{array}{c}25 \\
(17.24 \%)\end{array}$ \\
\hline
\end{tabular}

Concerning to statement $1,18(12.4 \%)$ students were strongly disagreed, and $42(28.96 \%)$ disagreed in opposition to happening. Although $53(36.55 \%)$ respondents were agreed and the remaining $33(22.75 \%)$ 
students strongly agreed that, their modules seem to meet their requirements and thematic interests. The majority agreements $(59.3 \%)$ assured that modules were more applicable to their requirements and thematic interests.

In terms of statement 2, $6(4.13 \%)$ students were strongly disagreed, and $34(23.44 \%)$ disagreed in light of outcomes. However, 66 (45.5\%) students were agreed and 39 (42.89\%) strongly agreed that modular speaking, reading and writing activities enable students better geared up to use English in their daily lesson. Greater number of respondents (88.39\%) supposed that modular speaking; reading and writing activities allow them to enhance their daily lecture.

In line with statement 3, $6(4.13 \%)$ students were strongly disagreed, and $26(17.93 \%)$ disagreed with relating to issue. In contrast, 65 (44.82\%) subjects were agreed and $48(33.1 \%)$ students strongly agreed that they do not get sufficient exposure to the language the modules were prepared. Thus, the majority agreements $(77.92 \%)$ commented that the language used for preparing modules seems deprived.

On the subject of statement 4, $17(11.72 \%)$ students were strongly disagreed and $51(35.17 \%)$ disagreed with the idea. Nevertheless, $43(29.65 \%)$ subjects were agreed and 34 (23.44\%) of them strongly agreed that there were high quality English medium modules in the college. Accordingly, the data (53.09\%) showed that there was somehow high and low quality modules used in the institution.

Regarding statement 5, 32 (22.06\%) students were strongly disagreed, 67 (46.2\%) students disagreed with the set of ideas. Despite the fact that $29(20 \%)$ subjects were agreed and $17(11.72 \%)$ strongly agreed that modules were free of any grammatical errors. The majority students $(68.26 \%)$ showed that there were grammatical, content, sequence, and arranging errors in modules. In line with the statement 6, $17(11.72 \%)$ students were strongly disagreed, and 50 (34.48\%) disagreed with the account of fact. However, 62 (42.75) students were agreed and the remaining $16(11 \%)$ learners strongly agreed that they can easily understand the contents of the module.

Concerning statement 7, about $22(15.17 \%)$ students were strongly disagreed, and 55 (37.93\%) disagreed in this way. Whereas, $43(29.65 \%)$ students were agreed and $25(17.24 \%)$ strongly agreed that modules were not distributed one to one. The overall rate $(53.1 \%)$ implies that there was a scarcity of learning resources in this college.

In terms of item 8 , about $25(17.24 \%)$ students were strongly disagreed, and $62(42.75 \%)$ disagreed with the statement. Although, $36(24.82 \%)$ subjects were agreed and $22(15.17 \%)$ learners strongly agreed that teachers were confident while using their modules. Students' disagreement $(59.99 \%)$ showed that instructors were less confident to use their modules.

In line with item 9, $28(19.3 \%)$ of students were strongly disagreed and $46 \quad(31.72 \%)$ of them also disagreed with the idea. On the other hand, 43 (29.65\%) respondents were agreed and $28(19.3 \%)$ strongly agreed with the idea. The average number of students $(51.02 \%)$ opposed that modules were not communicative, and enable them self-learning.

Regarding statement 10, $22(15.17 \%)$ students were strongly disagree, and $62(42.75 \%)$ disagree with the happening. However, $36(24.82 \%)$ students were agreed and 25 (17.24\%) of them also strongly agreed with the intended idea. Hence, $57.92 \%$ of students assured that there were no enough reference materials in the library.

\section{Conclusion}

Students' self-attitude towards the English medium of instruction showed that English was not superior medium of instruction to Amharic. However, English medium of instruction makes students' learning of the subject matter difficult. They face difficulty in order to reflecting, questioning \& answering in English. This implies that student's lack of English language proficiency was negatively influencing their lesson understanding. Therefore, students' low English proficiency leads them to incompetent and unproductive instruction and learning processes.

Moreover, foreign language anxiety has been challenging English medium of instruction at large. As previewed in the data students were facing difficulty to understand the language of instruction. These lead them problems regarding discussing, debating, answering and asking for clarification in English medium.

Students' perception towards their instructors indicated that instructors use their mother tongue while presenting lessons in the classroom. As the majority agreements $(91.68 \%)$ assured that instructors were facing difficulties while teaching different subjects in English medium. Accordingly, teachers who cannot speak English confidently and appropriately might provide incompetent to carry out their main responsibility in the classroom settings. In this case, student's mastery of English might be difficult.

Students' evaluation towards learning sources stated that modules were more applicable to their requirements and thematic interests. Greater number of respondents (88.39\%) supposed that modular speaking; reading and writing activities allow them to enhance their daily lecture.

Thus, the majority agreements $(77.92 \%)$ commented that the language used for preparing modules seems deprived. Accordingly, the data (53.09\%) showed that there was somehow high and low quality modules used in the institution. The overall rate $(53.1 \%)$ implies that there was a scarcity of learning resources in this college. Students' disagreement (59.99\%) showed that instructors were less confident to use their modules. The average 
number of students $(51.02 \%)$ opposed that modules were not communicative, and enable them self-learning. Hence, $57.92 \%$ of students assured that there were no enough reference materials in the library.

\section{Recommendation}

The situation of teachers' competence, support for student-centered learning, teachers' and students' English proficiency, supervision and support, effective use of English medium of instruction, diversity of processes and facilities ought to be improving. Therefore, further research in quality education in particular, English Medium of instruction in general supposed to be conducting in the future.

\section{Bibliography}

Ames, C. 1992. Classrooms: Goals, structures, and student motivation. Journal of Education Psychology, 84, 261-271.

Chang, Y. 2010. English-medium instruction in subject courses in tertiary education: Reactions from Taiwanese undergraduate students. Taiwan International ESP Journal, 2 (1), 55-84.

Clason, D. L., \& Dormody, T. J. (1994). Analysing data measured by individual Likert-type items. Journal of Agricultural Education, 35 (4), 31-35.

Coleman, J. A. 2006.English-medium teaching in European higher education. Language Teaching, 39 (1), 1-14.

Cots, J.M. 2012. Introducing English-medium instruction at the university of Lleida, Spain: Intervention Beliefs and Practices. In, A. Doiz, D. Lasagabaster \& J.M. Sierra (Eds.) English-Medium Instruction at Universities, Global Challenges. Multilingual Matters.

Csizer, K. and Dornyei, Z. 2005. The internal structure of language learning motivation and its relationship with language choice and learning effort. The Modern Language Journal, 89, I, 1936. Elaine, P. (1992). Effect of language anxiety in students. Michigan: West Michigan University.

Doiz, A., Lasagabaster, D., \& Sierra J.M. (Eds.). 2012. English-Medium Instruction at Universities.Global Challenges. Multilingual Matters.

Ellis, R. 1994. The study of second language acquisition. Oxford: Oxford University Press.

Gardner, R. C., \& Lambert, W. E. 1972. Attitudes and motivation in second language learning. Rowley, MA: Newbury House.

Hamers, J. F. \& Blanc, M. H. 2000. Bilingualism and bilingualism. (2nd Ed.).

Cambridge: Cambridge University Press.

Kırkgöz, Y. 2005. Motivation and student perception of studying in an English-medium university. Journal of Language and Linguistic Studies, 1 (1): 101-123.

Ministry of Education of Ethiopia. 1994. Education and Training Policy. Addis Ababa: St. George Printing Press.

Stoddart, John .1986. "The Use and Study of English in Ethiopian Schools”. Addis Ababa. 